\title{
ASPEK PERIZINAN DALAM PENDIRIAN PERSEROAN TERBATAS DENGAN SISTEM ONLINE SINGLE SUBMISSION
}

\author{
Made Karina Thalia Crisandyna, I Nyoman Sumardika, Desak Gde Dwi Arini \\ Fakultas Hukum Universitas Warmadewa, Denpasar - Bali, Indonesia
}

\begin{abstract}
Abstrak
Percepatan dan peningkatan penanaman modal dan berusaha perlu dilakukan dengan menerapkan pelayanan Perizinan Berusaha terintegrasi secara elektronik atau online single submission (OSS). Penelitian ini bertujuan untuk mengetahui proses pelaksanaan perizinan pendirian Perseroan Terbatas dengan sistem OSS dan kendala yang dihadapi oleh direksi dalam OSS dan upaya penanggulangannya. Penelitian ini merupakan penelitian hukum empiris dengan menggunakan tipe pendekatan yuridis empiris serta menggunakan sumber data primer dan data sekunder. Pengumpulan data dilakukan dengan observasi langsung ke lapangan dan selanjutnya dianalisis dengan menggunakan medote analisis kualitatif. Hasil penelitian ini menunjukkan bahwa proses pelaksanaan perizinan pendirian Perseroan Terbatas dilakukan secara online dengan mengakses web OSS dan melengkapi data-data sebagaimana yang terdapat pada sistem tersebut. Lembaga OSS kemudian akan menerbitkan NIB untuk mendapatkan Izin Usaha dan Izin Komersial atau Operasional termasuk untuk pemenuhan persyaratan Izin Usaha dan Izin Komersial atau Operasional. Selanjutnya, mengenai kendala yang dihadapi dalam sistem OSS adalah terkait dengan aspek regulasi, aspek sistem, aspek tata laksana, kurangnya sosialisasi, adanya tambahan biaya dalam penyesuaian maksud dan tujuan Perseroan Terbatas, dan pengaksesannya yang terjadi secara dua kali, baik secara online maupun penyerahan berkas. Dalam rangka upaya penanggulangan kendala yang ada, maka dibentuk satuan tugas yang terdiri dari Satuan Tugas Nasional, Satuan Tugas Kementerian/Lembaga, Satuan Tugas Provinsi, Satuan Tugas Kabupaten/Kota, pembaharuan sistem, seminar dan pembekalan mengenai sistem OSS.
\end{abstract}

Kata kunci: Perizinan; Perseroan Terbatas: Online Single Submission

\begin{abstract}
The acceleration and increase in investment and business needs to be done by implementing an integrated business licensing service online or online single submission (OSS). This study aims to determine the licensing process of establishing a Limited Liability Company with the OSS system and the constraints faced by the directors in OSS and their mitigation efforts. This research is an empirical legal research using empirical juridical approach type and using primary data sources and secondary data. Data collection is done by direct observation in the field and then analyzed using qualitative analysis methods. The results of this study indicate that the licensing process of establishing a Limited Liability Company is carried out online by accessing the OSS website and completing the data as contained in the system. The OSS Institution will then issue an NIB to obtain a Business License and a Commercial or Operational License including to fulfill the requirements for a Business License and a Commercial or Operational License. Furthermore, the obstacles faced in the OSS system are related to regulatory aspects, system aspects, governance aspects, lack of socialization, additional costs in adjusting the goals and objectives of the Limited Liability Company, and accessing them that occur twice, both online and file submission. In the context of overcoming existing obstacles, a task force was formed consisting of the National Task Force, Ministry / Institution Task Force, Provincial Task Force, District / City Task Force, system renewal, seminars and briefing on the OSS system.
\end{abstract}

Keywords: Licensing; Limited Liability Company; Online Single Submission

\section{PENDAHULUAN}

Untuk mencapai tujuan bernegara berkaitan dengan hal tersebut, penanaman modal harus menjadi bagian dari penyelenggaraan perekonomian nasional dan ditempatkan sebagai upaya untuk meningkatkan pertumbuhan ekonomi nasional, menciptakan lapangan kerja, meningkatkan pembangunan ekonomi berkelanjutan, meningkatkan kapasitas dan kemampuan teknologi nasional, 
mendorong pembangunan ekonomi kerakyatan, serta mewujudkan kesejahteraan masyarakat dalam suatu sistem perekonomian yang berdaya saing.

Pembangunan perekonomian nasional yang diselenggarakan berdasarkan demokrasi ekonomi dengan prinsip kebersamaan, efisiensi yang berkeadilan, berkelanjutan, berwawasan lingkungan, kemandirian, serta menjaga keseimbangan kemajuan dan kesatuan ekonomi nasional bertujuan untuk mewujudkan kesejahteraan masyarakat. Peningkatan pembangunan perkonomian nasional perlu didukung oleh suatu undang-undang yang mengatur tentang perseroan terbatas yang dapat menjamin iklim dunia usaha yang kondusif (Lambe, 2011).

Perseroan Terbatas merupakan suatu bentuk usaha dalam bidang ekonomi yang paling disukai saat ini, karena disamping pertanggungjawabannya yang bersifat terbatas, Perseroan Terbatas juga memberi kemudahan bagi pemilik (Pemegang saham) untuk mengalihkan perusahaannya (kepada setiap orang) dengan menjual seluruh saham yang dimilikinya pada perusahaan tersebut, serta keuntungan-keuntungan lainnya (Yani and Wijaya, 2003).

Perusahaan adalah keseluruhan perbuatan yang dilakukan secara terus-menerus, bertindak keluar, untuk memperoleh penghasilan, dengan cara memperdagangkan atau menyerahkan barang atau mengadakan perjanjian perdagangan (Abdulkadir, 2006). Perusahaan pada dasarnya merupakan suatu kegiatan yang dilakukan secara terus menerus dengan terang-terangan untuk memperolehkeuntungan (Hartono, 2007). Suatu perusahaan perseroan memerlukan suatu pelayanan Perizinan Terintegrasi Secara Elektronik, pelaksanaan Perizinan Pendirian Perseroan Terbatas menggunakan sistem manual yaitu dengan cara mendatangi kantor Pelayanan Terpadu Satu Pintu di Provinsi atau daerah tempat domisili dimana Perseroan tersebut didirikan, dengan menggunakan sistem manual tentu cara pendaftaran izin-izin juga dengan cara manual yaitu dengan cara mengisi formulir pengajuan izin apabila perseroan terbatas baru didirkan.

Undang-Undang Perseroan Terbatas (yang selanjutnya disebut UUPT) secara tegas menyatakan bahwa perseroan terbatas merupakan suatu badan hukum, yaitu suatu badan yang dapat bertindak dalam lalulintas hukum sebagai subyek hukum dan memiliki kekayaan yang dipisahkan dari kekayaan pribadi pengurusnya. Perseroan Terbatas adalah badan hukum yang merupakan persekutuan modal, didirikan berdasarkan perjanjian, melakukan kegiatan usaha dan modal dasar yang seluruhnya terbagi dalam saham-saham dan memenuhi persyaratan yang ditetapkan dalam undang-undang ini serta peraturan pelaksanaanya (Ginting, 2007).

Perseroan terbatas juga merupakan subjek hukum, yaitu subjek hukum mandiri atau persen astandi in judicio. Dia bisa mempunyai hak dan kewajiban dalam hubungan hukum sama seperti manusia biasa atau natural person atau naturliijke person, dia bisa menggugat ataupun digugat, bisa membuat keputusan dan bisa mempunyai hak dan kewajiban, utang-piutang, mempunyai kekayaan seperti layaknya manusia (Abdulkadir, 2006).

Dalam hal melengkapi hak dan kewajiban dalam hubungan hukum pada Perseroan Terbatas maka perseroan terbatas selaku badan usaha swasta harus memiliki izin-izin guna menjalankan kegiatannya secara legalitas. Untuk mencari atau mendapat suatu izin sebuah perusahaan yang akan menjalankan usaha atau bisnisnya maka sebuah perusahaan tersebut harus mengikuti suatu prosedur yang sesuai dengan peraturan perundangan yang berlaku (Widjaya, 2003).

Kementerian beserta dengan lembaga perizinan daerah setempat terus mengusahakan untuk bisa menerbitkan izin bagi suatu perusahaan dengan mempercepat dan meningkatkan dalam prosesnya karena kementerian ataupun lembaga perizinan daerah sudah seharusnya membantu dalam penerbitan izin usaha dan tidak justru menjadi penghambat dalam pengeluaran izin untuk perusahaanperusahaan yang telah sesuai dengan prosedur peraturan perundangan.

Pelayanan Terpadu Satu Pintu (yang selanjutnya disebut PTSP) yang berada ditingkat pusat ataupun ditingkat daerah harus lebih menekankan pada pelayanan yang lebih efektif serta modern dengan menyediakan suatu pelayanan pemberian izin yang mempunyai integeritas serta modern elektronik atau sekarang dikenal dengan Online Single Submission (yang selanjutnya disebut OSS). Akan tetapi dalam penerapannya seharusnya Perizinan lebih Berusaha Terintegrasi Secara Elektronik bersifat cepat dan meningkatan penanaman modal dan berusaha, tapi sering kali dalam prakteknya ditemukan beberapa kendala seperti error sistem dan kurangnya pemahaman dari para direksi perseoran terbatas tentang tata cara penggunaan dan akses Perizinan Berusaha Terintegrasi Secara Elektronik. 
Dari uraian pada latar belakang masalah tersebut, maka dapat ditemukan dua rumusan masalah yang akan dibahas dalam penelitian ini, yaitu bagaimana proses pelaksanaan perizinan pendirian PT dengan sistem OSS (Online Single Submission)? dan apasaja kendala yang dihadapi oleh direksi dalam OSS (Online Single Submission) tersebut dan upaya penanggulangannya? Tujuan penelitian ini, yaitu untuk mengetahui Proses pelaksanaan perizinan pendirian PT dengan sistem OSS (Online Single Submission) dan untuk mengetahui kendala yang dihadapi oleh direksi dalam OSS (Online Single Submission) tersebut dan upaya penanggulangannya.

\section{METODE PENELITIAN}

Jenis penelitian yang digunakan dalam penelitian ini adalah penelitian hukum empiris. Penelitian hukum empiris adalah penelitian yang berkaitan dengan hukum dan perilaku manusia. Jenis penelitian ini dilakukan dengan cara terjun langsung kelapangan untuk menemukan fakta-fakta dalam permasalahan yang ada di lapangan. Tipe pendekatan yang dilakukan dalam penelitian ini adalah pendekatan yuridis empiris yang merupakan pendekatan dengan melihat sesuatu kenyataan hukum di masyarakat. Dalam pendekatan yuridis empiris ini dapat ditemukan permasalahan dan penjelasan hubungan antara satu data dengan data yang lain sebagai suatu peristiwa. Pendekatan masalah yang digunakan dalam penelitian ini terkait dengan implikasi Peraturan Pemerintah Nomor 24 Tahun 2018 tentang Pelayanan Perizinan Berusaha Terintegrasi Secara Elektronik dan pendekatan yuridis sosiologis yang merupakan tipe pendekatan masalah dengan mengidentifikasikan dan mengkonsepsikan hukum sebagai institusi sosial yang riil dan fungsional dalam sistem kehidupan yang nyata. Pendekatan fakta sosial yang berhubungan dengan sistem OSS dan mengabungkannya dengan pendekatan perundang-undangan yang menjadi fokus sekaligus tema sentral suatu penulisan. Sumber data merupakan tempat dimana penulis memperoleh data dalam penelitian ini, yaitu dengan menggunakan data primer dan data sekunder.

1) Data primer adalah data yang terdiri atas hasil wawancara langsung dari narasumber dan responden mengenai sistem OSS. Wawancara ini dilakukan dengan informan yaitu Direksi PT.

2) Data Sekunder adalah sumber data penelitian yang diperoleh melalui media perantara atau secara tidak langsung yang berupa buku, catatan, bukti yang telah ada, atau arsip baik yang dipublikasikan maupun yang tidak dipublikasikan secara umum, yang terdiri dari bahan hukum primer dan bahan hukum sekunder.

Dalam penelitian ini dilakukan observasi langsung ke lapangan. Dengan mendatangi Dinas Perijinan Provinsi Bali dan Dinas Penanaman Modal dan Pelayanan Terpadu Satu Pintu Provinsi Bali. Selain itu juga dilakukan wawancara dengan para direksi pendiri PT yang menerapkan Perizinan Online. Teknik pengumpulan data yang digunakan oleh penulis dalam penulisan ini adalah studi kepustakaan atau studi dokumen, dimana teknik ini mempelajari, mencatat, dan membaca doktrindoktrin, catatan, literatur, perundang-undangan, jurnal, dan media internet yang berkaitan dengan pokok masalah yang berhubungan dengan masalah yang penulis teliti.

\section{HASIL PENELITIAN DAN PEMBAHASAN}

\section{Proses Pelaksanaan Perizinan Pendirian PT dengan Sistem OSS (Online Single Submission)}

Perizinan adalah pemberian legalitas kepada seseorang atau pelaku usaha/ kegiatan tertentu, baik dalam bentuk izin maupun tanda daftar usaha. Izin ialah salah satu instrumen yang paling banyak digunakan dalam hukum administrasi, untuk mengemudikan tingkah laku para warga (Hadjon 1993). Di dalam kamus istilah hukum, izin (vergunning) dijelaskan sebagai Perkenaan atau izin dari pemerintah yang disyaratkan untuk perbuatan yang pada umumnya memerlukan pengawasan khusus, tetapi yang pada umumnya tidaklah dianggap sebagai hal-hal yang sama sekali tidak dikehendaki (Ridwan, 2006). Sebelum di keluarkannya Peraturan Presiden Nomor 91 Tahun 2017 tentang Percepatan Pelaksana Berusaha dan peraturan Pemerintah nomor 24 Tahun 2018 tentang Pelayanan Perizinan Berusaha Terintegrasi Secara Elektronik, pelaksanaan Perizinan Pendirian Perseroan Terbatas menggunakan sistem manual yaitu dengan cara mendatangi kantor Pelayanan Terpadu Satu Pintu di Provinsi atau daerah tempat domisili dimana Perseroan tersebut didirikan, dengan menggunakan sistem manual tentu cara pendaftaran izin-izin juga dengan cara manual yaitu dengan cara mengisi formulir pengajuan izin apabila perseroan terbatas baru didirkan.

Berdasarkan hasil wawancara pada hari selasa, tanggal 04 Januari 2020 dengan Bapak Bergas selaku Direktur PT Tantra Bali Indonesia yang pertama kali harus dipenuhi oleh PT yang baru 
didirikan adalah izin tanda daftar perusahaan yang menjadi dasar perusahaan atau perseroan tersebut bisa berdiri dan menjalankan kegiatannya, formulir tanda daftar perusahaan tersedia di Kantor Pelayanan Terpadu Satu Pintu provinsi atau Kabupaten/ Kota selain, mengisi formulir ada beberapa persyaratan lain yang harus di bawa dan dilampirkan pada formulir tanda daftar perusahaan yaitu Akta pendirian Perseroan Terbatas yang dibuat dihadapan Notaris dan Surat Keputusan dari Kementerian Hukum dan Hak Asasi Manusia, Surat keterangan Tempat Usaha, NPWP PT, dokumen penguasaan tempat usaha (bukti kepemilikan tempat usaha), IMB (Ijin Mendirikan Bagunan), dan Pajak Bumi Bangunan dari Kantor Perseroan terbatas tersebut, Pas foto Direksi perseroan, surat kuasa (apabila pengajuan izin dilakukan oleh jasa pihak lain dan bukan dilakukan oleh Direksi dari perseroan tersebut) dan beberapa surat pernyataan lain yang dibutuhkan, kemudian setelah semua persyaratan dilengkapi, berkas pengajuan izin-izin akan diperiksa oleh pegawai dari PTSP selama kurang lebih 14 (empat belas) hari kerja, apabila tidak ada kekurangan dan kendala berkas pengajuan izin akan disetujui dan ditandatangani oleh Kepala Dinas Penanaman Modal dimana izin itu diajukan setelah tanda daftar perusahaan selesai barulah perseroan bisa melanjutkan pengajuan izin-izin lainnya seperti Surat Izin Usaha Perdagangan, Izin Lokasi dan izin-izin lainnya yang juga diajukan melalui kantor PTSP provinsi atau tempat dimana domisili PT tersebut didirikan dengan proses kerja yang sama yaitu kurang lebih 14 (empat belas) hari kerja.

Dalam rangka mewujudkan visi dari peraturan perundangan yang berlaku maka kementerian serta lembaga perizinan yang berada ditingkat pusat atau daerah berusaha meningkatkan pelayanan dalam penerbitan izin bagi suatu perusahaan. Pelayanan yang mempunyai integeritas tinggi serta dengan sistem yang modern yaitu dengan cara online dilakukan guna meningkatkan dan mempercepat suatu perusahaan penanam modal yang akan memulai usaha atau bisnisnya. Dalam proses pengajuannya direksi atau komisaris harus memastikan bahwa pendirian perseroan dilakukan setelah diterbitkannya Peraturan Pemerintah Nomor 24 Tahun 2018 tentang Pelayanan Perizinan Berusaha Terintegrasi Secara Elektronik karena, apabila PT tersebut didirkan sebelum adanya Peraturan Pemerintah Nomor 24 Tahun 2018 tentang Pelayanan Perizinan Berusaha Terintegrasi Secara Elektronik maka PT tersebut perlu melakukan perubahan atau lebih tepatnya penyesuaian maksud dan tujuan PT sesuai Klasifikasi Baku Lapangan Usaha Indonesia tahun 2017, penyesuaian tersebut dilakukan dengan cara merubah anggaran dasar PT dengan akta perubahan Notaris dan keputusan perubahan yang dikeluarkan oleh kementerian Hukum dan Hak Asasi Manusia, setelah maksud dan tujuan PT sudah sesuai dengan Klasifikasi Baku Lapangan Usaha Indonesia tahun 2017 direksi dan komisaris PT bisa mengakses izin Nomor Induk Berusaha (yang selanjutnya disebut NIB), NIB sendiri merupakan identitas pelaku usaha yang diterbitkan oleh Lembaga OSS, NIB juga merupakan izin pengganti dari Tanda Daftar Perusahaan, Angka Pengenal Impor dan hak akses kepabeanan yang juga memiliki fungsi yang sama yaitu merupakan dasar izin bagi pendirian perseroan terbatas yang akan melaksanakan dan/atau menjalakan kegiatan usahanya.

Pengajuan izin-izin dilakukan secara online dengan mengakses web OSS yaitu https://www.oss.go.id/ setelah mengakses web tersebut direksi atau komisaris bisa melakukan sendiri proses pengajuan dari izin-izin yang diperlukan dengan cara medaftar terlebih dahulu pada web OSS dengan cara mengisi nama, nomor Induk kependudukan atau passport (apabila direksi atau komisaris merupakan Warga Negara Asing), nama sesuai Kartu Tanda penduduk, tanggal lahir, negara asal, jenis pelaku usaha, e-mail perusahaan, dan nomor telepon apabila data- data tersebut sudah diisi dengan benar username atau biasa dikenal dengan id pengguna serta kata sandi akan dikirimkan melalui e-mail perushaan yang digunakan saat pendaftaran di web OSS, setelah itu direksi atau komisaris mempunyai akun atau hak akses di OSS dan bisa memulai untuk mengakses izin NIB yang diperlukan sebagai izin dasar bagi PT.

Berdasarkan hasil wawancara pada hari selasa, tanggal 04 Januari 2020 dengan Bapak Bergas selaku Direktur PT Tantra Bali Indonesiabeliau memaparkan keuntungan yang didapatkan dalam menggunakan OSS atau izin dengan sistem online ini adalah apabila dalam pengajuan izin secara manual proses kerja dari PTSP akan berlangsung selama 14 (empat belas) hari kerja, sedangkan pada sistem OSS menggunakan Automatic Approval yang artinya sepanjang memenuhi persyaratan pada saat mengakses izin secara online maka izin yang diakses akan bisa langsung tercetak, kemudian keuntungan lainnya adalah dalam mengakses izin NIB maka pengakses atau Direksi dan komisaris PT bisa langsung mendapatkan izin Usaha, Izin Lokasi dan Izin Lingkungan namun, belum berlaku secara efektif ada beberapa data dan persyaratan yang harus dilengkapi untuk mengefektifkan izin- 
izin tersebut contohnya seperti pemenuhan komitmen prasarana dasar sesuai kebutuhan usaha yaitu Izin Lokasi, Izin Lingkungan (UKL/UPL atau AMDAL) dan/atau Izin Mendirikan Bangunan (IMB) dan SLF kepada DPMPTSP sesuai lokasi proyek.

Kemudahan berusaha dalamproses pengajuan dari izin-izin yang diperlukan dengan cara medaftar terlebih dahulu pada web OSS dengan cara mengisi nama, nomor Induk kependudukan atau passport (apabila direksi atau komisaris merupakan Warga Negara Asing), nama sesuai Kartu Tanda penduduk, tanggal lahir, negara asal, jenis pelaku usaha, e-mail perusahaan, dan nomor telepon apabila data-data tersebut sudah diisi dengan benar username atau biasa dikenal dengan id pengguna serta kata sandi akan dikirimkan melalui e-mail perushaan yang digunakan saat pendaftaran di web OSS, setelah itu direksi atau komisaris mempunyai akun atau hak akses di OSS dan bisa memulai untuk mengakses izin NIB yang diperlukan sebagai izin dasar bagi PT yang merupakan tujuan pemerintah pusat dalam pengadaan sistem OSS namun dalam penerapannya tidak jarang di temukan kendala yang dialami entah dari sistem ataupun kurangnya pemahaman masyarakat mengenai cara penggunaan sistem OSS.

Perbedaan penyediaan pelayanan dan kemampuan akses setiap daerah juga menjadi masalah yang cukup di perhitungkan pada pelaksanaan perizinan secara online, karena dengan adanya perizinan secara online tentu dasar dalam pengaksesannya merupakan jaringan internet, listrik, dan pengetahuan mengenai cara pengaksesan dengan sistem online, namun dikarenakan tiap-tiap daerah memiliki kemampuan berbeda dalam hal jaringan internet, pengadaan listrik, dan mengenal serta mengakses sistem perizinan secara online tentu merupakan kendala yang patut dipikirkan kembali oleh pemerintahkhususnya pemerintah pusat, apakah sistem online ini sudah benar-benar siap digunakan dan diterapkan di masyarakat.

\section{Kendala yang Dihadapi oleh Direksi dalam OSS (Online Single Submission) dan Upaya Penanggulangannya}

Beberapa hambatan itu menjadi temuan oleh Komite Pemantau Pelaksanaan Otonomi Daerah yang selanjutnya disebut KPPOD. KPPOD melakukan studi evaluasi setahun implementasi OSS. Dalam temuan KPPOD, Direktur Eksekutif KPPOD Robert Endi Jaweng menyatakan bahwa setidaknya terdapat tiga masalah utama dalam pelaksanaan OSS yakni dari aspek regulasi, aspek sistem dan aspek tata laksana.

Dari aspek regulasi ada tiga hal yang menjadi catatan. Apa saja? Pertama, adanya disharmoni aturan antara Norma, Standar, Prosedur dan Kriteria yang,selanjutnya di sebut NSPK terhadap Peraturan Presiden mengenai OSS, contohnya NSPK Perindustrian dan NSPK Pariwisata. Akibatnya, terjadinya tambahan prosedur pemenuhan komitmen di sektor peridustrian. Kedua, NSPK tidak lengkap sehingga Pemerintah Daerah (PEMDA) memutuskan untuk menggunakan peraturan lama dan tidak sinkron dengan OSS. Ketiga, substansi NSPK sektor tidak memadai. Kemudian aspek sistem, mayoritas daerah kesulitan mengintegrasikan OSS, database perizinan masih belum terklarifikasi, tidak tersedia fitur E-Payment, tidak semua daerah memiliki Rencana Detil Tata Ruang (RDTR), dan adanya tambahan prosedur di aplikasi K/L yang justru dinilai menghambat proses.

Berdasarkan hasil wawancara pada hari jumat, tanggal 27 Desember 2019 dengan ibu Desak Nyoman Juli Astini selaku Direktur PT Anugerah Guna Sentosabeliau memaparkan dalam keuntungan penggunaan sistem OSS adalah dengan mengakses izin NIB maka pengakses atau Direksi dan komisaris PT bisa langsung mendapatkan izin Usaha, Izin Lokasi dan Izin Lingkungan namun, belum berlaku secara efektif ada beberapa data dan persyaratan yang harus dilengkapi untuk mengefektifkan izin-izin tersebut contohnya seperti pemenuhan komitmen prasarana dasar sesuai kebutuhan usaha yaitu Izin Lokasi, Izin Lingkungan (UKL/UPL atau AMDAL) dan/atau Izin Mendirikan Bangunan (IMB) dan SLF kepada Penanaman Modal dan Pelayanan Terpadu Satu Pintu sesuai lokasi proyek. Pembaruan sistem dilakukan untukmenambah kinerja pada sistem OSS juga dilakukan oleh pemerintah pusat guna mempermudah dan menanggulangi kendala yang sering terjadi pada sistem seperti error sistem atau terkendalanya cetak NIB pada sistem OSS.

Berdasarkan hasil wawancara pada hari selasa, tanggal 04 Januari 2020 dengan Bapak Bergas selaku Direktur PT Tantra Bali Indonesia perlu diadakannya seminar serta pembekalan kepada masyarakat ditingkat daerah atau Provinsi juga merupakan salah satu upaya yang dilakukan 
pemerintah guna memberikan pemahaman mengenai sistem OSS sendiri walaupun seminar tersebut baru dilakukan setelah kurang lebih 1 (satu) tahun sistem OSS sudah diterapkan dan digunakan oleh masyarakat.

\section{SIMPULAN DAN SARAN}

1. Simpulan

Dari penjelasan pendahuluan sampai dengan hasil penelitian dan pembahasan, maka dapat disimpulkan yaitu:

a. Bahwa pelaksanaan perizinan pendirian PT dengan sistem OSS dilakukan oleh direksi atau komisaris dengan terlebih dahulu memastikan bahwa pendirian perseroan dilakukan setelah diterbitkannya Peraturan Pemerintah Nomor 24 Tahun 2018 tentang Pelayanan Perizinan Berusaha Terintegrasi Secara Elektronik.Lembaga OSS kemudian akan menerbitkan NIB yang merupakan identitas berusaha dan digunakan oleh direksi atau komisaris untuk mendapatkan Izin Usaha dan Izin Komersial atau Operasional termasuk untuk pemenuhan persyaratan Izin Usaha dan Izin Komersial atau Operasional.

b. Bahwa kendala yang dihadapi dalam sistem OSS adalah terkait dengan aspek regulasi yaitu adanya disharmoni aturan antara NSPK terhadap Peraturan Presiden mengenai OSS dan NSPK masih kurang lengkap. Selanjutnya, kendala dalam aspek sistem bahwa, mayoritas daerah kesulitan mengintegrasikan OSS, database perizinan masih belum terklarifikasi, tidak tersedia fitur E-Payment, tidak semua daerah memiliki Rencana Detail Tata Ruang, dan adanya tambahan prosedur di aplikasi K/L. Kendala lainnya terkait dengan aspek tata laksana tataran regulasi, bahwa OSS meringkas tata laksana perizinan saat memulai usaha, memberikan kepastian waktu untuk pemenuhan komitmen, dan tidak ada perubahan dalam hal besaran biaya.Selain itu, dilakukan pembaharuan sistem guna meningkatkan kinerja pada sistem OSS agar dapat mengurangi sistem eror atau terkendalanya cetak NIB. Selanjutmya, diadakannya seminar serta pembekalan kepada masyarakat ditingkat daerah atau Provinsi guna memberikan pemahaman mengenai sistem OSS.

\section{Saran}

Dalam hal ini dinas perizinan dan penanaman modal perlu memberikan pemahaman secara jelas pada masyarakat mengenai regulasi terkait dengan sistem OSS, sehingga masyarakat dapat menggunakan sistem tersebut sesuai dengan prosedur yang ada. Selain itu, Pemerintah perlu untuk terus meningkatkan dan melakukan pembaharuan sistem, agar dalam penggunaanya dapat mempermudah masyarakat dan meminimalisir sistem eror maupun gangguan lainnya. Selanjutnya, Pemerintah perlu melakukan sosialisasi dan pengawasan terhadap sistem OSS tersebut sehingga percepatan dan peningkatan penanaman modal dan berusaha melalui pelayanan perizinan berusaha terintegrasi secara elektronik dapat terwujud dengan baik.

Pihak-pihak dalam hal ini khususnya Direksi dan Komisaris yang mewakili Perseroan Terbatas perlu untuk memahami syarat, prosedur dan regulasi yang ada agar dapat meminimalisir kesalahan pada saat melakukan perizinan dengan menggunakan sistem OSS. Selain itu, pihak-pihak tersebut juga harus memiliki komitmen untuk memenuhi persyaratan lzin Usaha dan/atau lzin Komersial atau Operasional. Selanjutnya, pihak-pihak tersebut juga perlu membantu Pemerintah dalam rangka melakukan sosialis mengenai sistem OSS kepada pelaku usaha lainnya.

\section{DAFTAR PUSTAKA}

Abdulkadir, Muhammad. 2006. Hukum Perusahaan Indonesia. Bandung: PT Citra Aditya Bakti. Ginting, Jamin. 2007. Hukum Perseroan Terbatas. Bandung: PT. Cipta Aditya Bakti.

Hadjon, Philipus M. 1993. Pengantar Hukum Perizinan. Surabaya: Yuridika.

Hartono, Sri Redjeki. 2007. Hukum Ekonomi Indonesia. Malang: Bayumedia Publishing.

Lambe, Devie. 2011. "Peran Dan Tanggung Jawab Notaris Dihubungkan Dengan Kinerja Sistem Administrasi Badan Hukum (SABH) Dalam Pendirian PT." Universitas Indonesia.

Rai Widjaya, I. G. 2003. Hukum Perusahaan Dan Undang-Undang Dan Peraturan Pelaksanaan Di Bidang Usaha. Jakarta: Kesaint Blanc.

Ridwan, HR. 2006. Hukum Administrasi Negara. Jakarta: PT. Raja Grafindo Persada.

Yani, Ahmad and Gunawan Wijaya. 2003. Perseroan Terbatas. Jakarta: PT. Raja Grafindo Persada. 